\title{
Budżet obywatelski w Katowicach i jego konsekwencje w przestrzennym zagospodarowaniu miasta
}

\section{Karolina Studencka}

\author{
Katedra Ksztaltowania Przestrzeni Komunikacyjnych, Wydziat Architektury, \\ Politechnika Krakowska im.Tadeusza Kościuszki, e-mail: studencka.karolina@gmail.com
}

Streszczenie: Budżet obywatelski to metoda dysponowania miejskimi pieniędzmi zdobywająca coraz szersze poparcie w naszym Kraju, a na świecie stosowana już od dziesięcioleci. Nadchodzi czas na refleksję jak takie dysponowanie środkami wpływa na kształt i organizację miasta, oraz jego poszczególnych dzielnic. Na podstawie konsultacji z mieszkańcami Katowic, które idee budżetu wdrażają i udoskonalają od 2 lat, podejmuję próbę zdiagnozowania zagrożeń związanych z tego typu rozwiązaniem, oraz uchybień w procedurach nim powodujących. Prowadzi to do konstruktywnych wniosków i opracowania swego rodzaju instrukcji naprawy procedur związanych z Budżetem Obywatelskim. $\mathrm{W}$ obecnym kształcie, niesie on ze sobą poważne zagrożenia związane $\mathrm{z}$ dezintegracją tkanki miejskiej. Może doprowadzić do pogłębiania się nierówności w stopniu rozwoju poszczególnych dzielnic, oraz bezmyślnego powielania podobnych do siebie funkcji W swoim bezpośrednim sąsiedztwie. W wielu przypadkach, poprzez przesuniecie pieniędzy z jednostek organizacyjnych gminy, pod władanie obywateli prowadzi również do zaspokajania potrzeb drugorzędnych w pierwszej kolejności. Pomimo krytycznego podejścia, nie staram się kompromitować takiego sposobu rozdysponowania środków, uważając go za wartościowe narzędzie jeśli chodzi o kształtowanie naszych przestrzeni miejskich, jak i mechanizm służący budowaniu tzw. Społeczeństwa Obywatelskiego.

Słowa kluczowe: Budżet obywatelski, Katowice, konsultacje społeczne, diagnoza społeczna, planowanie przestrzenne.

\section{Historia pojęcia}

Budżet Obywatelski ${ }^{1}$ (dalej BO) wywodzi się z szerzej zakrojonego trendu, budżetu partycypacyjnego, zapoczątkowanego w $1989^{2}$ roku w ponadmilionowym brazylijskim mieście Porto Alegre. W ramach jego wdrażania mieszkańcy zostali w formie sąsiedzkich, regionalnych i okołomiejskich zgromadzeń włączeni w proces decyzyjny dotyczący całości środków którymi dysponowało miasto. W ciągu 4 lat, liczba obywateli korzystających z tej możliwości wzrosła z niespełna tysiąca do 50 tysięcy $^{3}$. Podobne mechanizmy zaczęły być od tej pory lawinowo wprowadzana w innych miastach Brazylii i całej Ameryki Łacińskiej. W 2008 r. było ich już ponad 200 tys,, a w 2010 ok. 510 tys.

\footnotetext{
${ }^{1}$ Pojęcia Budżet Obywatelski używam w niniejszym opracowaniu jako wąskiego określenia funkcjonującego w Polsce procesu wydatkowania środków publicznych w określonym zakresie, uzależnionego w formie nie wiążącej, od inicjatywy i głosowania obywateli miasta.

2 Sam Budżet wprowadzony został w roku 1990, którą to datę podają niektóre źródła.

3 Dane podawane za M. Szaranowicz-Kusz, Budżet Partycypacyjny. Jak mieszkańcy mogą współdecydować o budżecie miasta? , s. 6-7.
} 
Karierę Budżetu Obywatelskiego w naszym kraju należy uznać za niesłychanie błyskotliwą. Jeszcze w 2005 r. pomysł oddania pewnej puli pieniędzy z środków finansowych miasta lub dzielnicy pod dyspozycję obywateli uważany był za anarchistyczną herezję a już w 2011 r. pilotażowy proces wprowadzony został w Sopocie. W 2015 r. stał się on sposobem planowania pewnej części wydatków w 147 gminach w Polsce ${ }^{5}$, a w 2016 r. obywatele naszego kraju będą mieli do rozdysponowania, w sumie ponad $318,5 \mathrm{mln} \mathrm{zf}^{6}$ $\mathrm{z}$ budżetu miast i dzielnic, z którymi się identyfikują ${ }^{7}$, co jest niemalże podwojeniem kwoty w stosunku do roku $2014^{8}$.

W praktyce jednak, polski BO pozostaje jedynie cieniem brazylijskiego pierwowzoru Budżetu Partycypacyjnego, a klasyfikowanie go jako formy realnej demokracji należy uznać za podejście życzeniowe. Wzorowany na założeniach swoich europejskich pierwowzorów i podobnie jak procedury wprowadzane wcześniej w Wielkiej Brytanii czy Krajach Skandynawskich obejmuje nie więcej niż $4 \%$ budżetu gminy ${ }^{9}$, a zazwyczaj wahając się jednak pomiędzy $0.5-1 \%$.

\section{Stan badań}

Za punkt wyjścia do moich badań nad BO przyjmuje opracowania dotyczące budżetu partycypacyjnego i partycypacji społecznej. Za wybitnego badacza tematu należy uznać Giovanni'ego Allegretti, ale swoją cegiełkę dołożyli również mniej popularni Gianpaolo Baiocchi, Yves Sintomer, Yves Cabannes czy Sergio Baierle.

W Polsce za publikację prekursorską wśród dotyczących tego zagadnienia uznać należy wydany w 2007 r. a opracowany przez Rafała Górskiego wolumin „Bez Państwa. Demokracja uczestniczaca $w$ działaniu”, który do dziś pozostaje jednym z najobszerniejszych i najbardziej wyczerpujących polskich opracowań zagranicznych praktyk związanych z Budżetem Partycypacyjnym. Z licznych późniejszych badaczy tego tematu, wymienić należy przynajmniej Dariusza Kraszewskiego, Karola Mojkowskiego, Wojciecha Kębłowskiego ${ }^{10}$ czy Joannę Erbel. Monitorowaniem praktyk związanych z tą tematyką oraz upowszechnianiem w naszym kraju dotyczących jej wydawnictw obcojęzycznych zajmują się też liczne instytucje kultury. Wśród nich Instytut Obywatelski, Fundacja im. Stefana Batorego, Fundacja Pole Dialogu, Fundacja i Pracownia Innowacji Obywatelskich „Stocznia" czy Fundacja Nowej Kultury Bęc Zmiana czy Wydawnictwo Krytyki Politycznej. Dostępne opracowania zasadniczo podzielić można na trzy grupy. Pierwsza z nich dotyczyć będzie ewaluacji funkcjonujących w poszczególnych miastach procedur BO oraz systematyzowania związanych z nimi danych liczbowych. Druga odnosić się będzie do praktyk partycypacji ogólnie i podejmować próby tworzenia jej podręczników. Za trzecią, reprezentowaną najmniej licznie, uznać można rozważania nad wpływem BO na przestrzeń naszych miast w ujęciu urbanistycznym i planistycznym.

\footnotetext{
${ }^{4}$ Za Kacper Pobłocki, Prawo do odpowiedzialności, jako wstęp do wyd. polskiego: Koszmar Partycypacji, Markus Miessen, Fundacja Nowej Kultury Bęc Zmiana, Warszawa 2013.

${ }^{5}$ Informacje publikowane na stronie http://bp.partycypacjaobywatelska.pl/porownywarka-budzetow/, dostep dnia 15.01.2016.

${ }^{6}$ Informacje znalezione na stronie http://budzetyobywatelskie.pl/, dnia 15.01.2016.

${ }^{7}$ Uprawnienia do głosowania $\mathrm{w}$ danej dzielnicy nie zawsze związane jest z kryterium zamieszkania / zameldowania na jej obszarze, np: warszawa dalej swoim mieszkańcom prawo do glosowania w dowolnej, ale tylko jednaj dzielnicy.

${ }^{8}$ D. Kraszewski, K. Mojkowski, Budżet Obywatelski w Polsce, Fundacja im. Stefana Batorego, Warszawa 2014.

9 tamże, s. 6-7, [3].

10 Budżet Partycypacyjny ewaluacja,oraz Budżet Partycypacyjny instrukcja obsługi.
} 


\section{Metodologia badań}

W okresie od sierpnia do listopada 2015 roku grupa osób ${ }^{11}$ współpracujących z „Fundacją Napraw Sobie Miasto” w ramach pierwszej edycji projektu „Miejskia Szychta” przeprowadziła w Katowicach proces Ewaluację procedury BO. Bezpośrednie efekty tej pracy zebrane zostały w publikacji pt: „Raport, zawierajacy wnioski mieszkanek oraz mieszkańców Katowic dotyczące Budżetu Obywatelskiego’. Jest to pozbawiony komentarza zapis uwag zgłoszonych przez uczestników ewaluacji. Został on złożony w Urzędzie Miasta. Proces ewaluacyjny zawężony był do osób zgłaszających swoje projekty na BO w poprzednich jego edycjach $[2015,2016]^{12}$. W niniejszym opracowaniu komentuje niektóre z wyników procesu ewaluacji w kontekście bazy wiedzy stworzonej na ten temat przez jego badaczy. W ramach przygotowań wykonane zostały również stosowne badania gabinetowe, w tym analizy projektów zrealizowanych w ramach pierwszej edycji Budżetu Obywatelskiego w mieście Katowice, realizowanych w 2015 r.

\section{Cel opracowania}

W tekście pominę polityczne oraz socjologiczne aspekty Budżetu Obywatelskiego ani tego jak sama procedura ma się do realnego procesu partycypacji społecznej. Pragnę jednak zaznaczyć, że jak zwykła mawiać D. Brillenburg ${ }^{13}$ :

„Urbanistyka, to zamrożona polityka”

Zajmując się urbanistycznymi i planistycznymi konsekwencjami BO, przyjmuje że przede wszystkim jest to procedura polityczna i nie jest moim celem całościowa krytyka tego przedsięwzięcia z pozycji zagrożeń urbanistycznych które ze sobą niesie. Nie można bowiem traktować jako podstawowego narzędzia zaspokojenia inwestycyjnych potrzeb miasta, programu mającego do dyspozycji ok. 1\% jego budżetu. Uważam za to, że niesie on ze sobą potencjał „miastotwórczy” w jego warstwie socjologicznej, pozwalający przy odpowiednich założeniach pozyskiwać dla miasta obywateli wśród ludzi będących dotychczas jedynie jego użytkownikami ${ }^{14}$ oraz budować zanikające $\mathrm{w}$ procesie metropolizacji miast więzi społeczne pomiędzy jego mieszkańcami.

Wskazując zagrożenia dla kształtu Polskich miast płynące z uchybień proceduralnych samego BO oraz [lub przede wszystkim] rzeczywistości prawnej polskiego systemu gospodarki przestrzennej, w której on funkcjonuje. Postaram się zaproponować narzędzia prewencyjne, porządkujące i ułatwiające kontrolę wpływu BO na kształt urbanistycznej tkanki miasta.

11 Skład osobowy zgodny z listą autorów, Raport, zawierający wnioski mieszkanek oraz mieszkańców Katowic dotyczące Budżetu Obywatelskiego, dostępnego pod adresem:

http://issuu.com/paweozyrysjaworski/docs/raport.

12 Konsultacje dotyczące każdej z edycji odbywają się w roku poprzedzającym, a więc miały one miejsce w latach 2014 i 2015.

13 David Brillenburg, członek czylijskiego kolektywu Urban Think Thank [UTT], realizującego projekty oraz analizującego procesy zachodzące w południowoamerykańskich slumsach. Wypowiedź cytowana za J. McGuirk, Radykalne Miasta, s. 151.

14 Obywatele i użytkownicy definiowani wg. B. Jałowiecki, „Czyje jest miasto” w [3]. 


\section{Tło prawne}

W założeniu Ustawy o Planowaniu i Zagospodarowaniu Przestrzennym ${ }^{15}$, głównym narzędziem porządkującym gospodarkę przestrzenną w Polsce po 2003 r. powinny być miejscowe Plany Zagospodarowania Przestrzennego (MPZM). Trudno jednak uznać, że spełniają one swoją rolę gdy wg. stanu na rok 2013 r. pokrywały one $28,6 \%$ powierzchni $\mathrm{kraju}^{16}$, co daje wzrost względem $2010 \mathrm{r}$. rzędu 2,2\% powierzchni ${ }^{17}$. W praktyce więc, pozwolenia na budowę wydaje się wciąż głownie na podstawie narzędzia w zamyśle spełniającego rolę pomocniczą i mającego funkcjonować tymczasowo, czyli Warunków Zabudowy (WZ). Głównym niebezpieczeństwem wiążącym się z tak powszechnym zastosowaniem WZ, jest całkowity brak podporządkowania poszczególnych decyzji inwestycyjnych w mieście jakiejkolwiek całościowej wizji jego rozwoju i uzależnienie ich od indywidualnych, jednostkowych decyzji poszczególnych urzędników. W efekcie stwierdzić można za Maciejem Nowakowskim ${ }^{18}$ : ,, Głównym sprawca przestrzennego chaosu, wzrastajacego $w$ Polsce co najmniej od trzydziestu lat, a spotegowanego w ostatnim dwudziestoleciu, jest brak przestrzennej polityki państwa $i$ niedostrzeganie jej potrzeby, oraz niespotykana w Europie liberalizacja gospodarki przestrzennej."

Działający w takiej przestrzeni program BO, pozwala na zabudowanie dowolnej należącej do miasta działki według indywidualnego pomysłu mieszkańca lub grupy mieszkańców miasta, jeśli tylko poparty będzie odpowiednią oprawą graficzną i marketingiem, zdolnym przekonać do głosowania na ten projekt wystarczającą ilość uprawnionych. Sytuacja taka w sposób oczywisty staje się szkodliwą dla możliwości koordynacji procesów inwestycyjnych $\mathrm{w}$ mieście i racjonalnego wykorzystania zasobów gruntu, którym ono dysponuje.

\section{Analiza wybranych przypadków}

1\# Osiedle Witosa to jeden z najbardziej prestiżowych sdresów w Katowicach. Są tu Parki i skwery, boiska dla młodzieży i place zabaw dla dzieci, są specjalne ogrodzone wybiegi dla psów i przestrzenie dedykowane dla seniorów. Osiedle Witosa jest więc terenem gęsto zaludnionym a jego zadowoleni, posiadający wysokiej jakości przestrzenie publiczne mieszkańcy są zintegrowanym społeczeństwem i chętnie włączają się w różnego rodzaju akcje społeczne, takich jak BO. Osiedle Witosa posiada wielu mieszkańców, dysponuje też więc dużymi środkami z budżetu, na realizację projektów w ramach BO. Zadowoleni mieszkańcy Osiedla Witosa postanawiają więc wybudować sobie na jednym z osiedlowych placów, (notabene, przykościelnym), akomodującym już teraz kilka z wymienionych powyżej funkcji, będącym w dobrym stanie technicznym i licznie odwie-

15 Dz.U. 2003 Nr 80 poz. 717, USTAWA z dnia 27 marca 2003 r. o planowaniu i zagospodarowaniu przestrzennym.

16 Analiza stanu i uwarunkowań prac planistycznych $w$ gminach $w 2013$ roku, SYNTEZA, Zespół autorski: Przemysław Śleszyński (koordynacja) Tomasz Komornicki, Aleksandra Deręgowska, Beata Zielińska, Opracowanie wykonane dla Departamentu Polityki Przestrzennej Ministerstwa Infrastruktury i Rozwoju, Warszawa 2013, dostępna:

https://www.igipz.pan.pl/tl files/igipz/ZGMiL/Aktualno\%C5\%9Bci/Streszczenie za 2013.pdf.

17 Barbara Prus, Sytuacja Planistyczna w Polsce - Studium Porównawcze, Infrastruktura i Ekologia Terenów Wiejskich, Nr 2/II/2012, Polska Akademia Nauk, Oddział w Krakowie, s. 123-135 Komisja Technicznej Infrastruktury Wsi.

18 Maciej Nowakowski, Sto lat planowania przestrzeni polskich miast (1910 -2010), współpraca Bańskowska B., Oficyna Naukowa, Warszawa 2013, s. 394. 
dzanym, fontannę na 400 tysięcy złotych ${ }^{19}$. Mieszkańcy Osiedla Witosa, w ramach BO mają do tego pełne prawo.

Za tą historią kryją się jednak przynajmniej dwie smutniejsze. Historyczna dzielnica miasta, zwana Załęską Hałdą, w obecnym podziale administracyjnym Katowic podzielona jest pomiędzy dzielnice Osiedle Witosa, Załęska Hałda Brynów oraz Załęże. Dzieci nie mają tu gdzie grać w piłkę, nie ma placów zabaw, skate parków ani oferty przestrzeni publicznych skierowanych dla osób starszych. I nie będzie, bo to tereny słabo zaludnione, niedoinwestowane i zapomniane przez władze miasta. Skazane na powolne popadanie w niebyt, niewygodne przysiółki biedy i przestępczości których mieszkańcy nie wierzą, że mogą od miasta coś dostać i nie angażują się w jego życie. Jak wspominałam wcześniej, $\mathrm{BO}$ nie jest sposobem na rewitalizacje przestrzeni miejskich w całościowym ujęciu. Posiada na ten cel, zdecydowanie zbyt skromne środki. Ma jednak potencjał przeprowadzenia skutecznego procesu akupunktury miasta. W ramach której zakłada się, że za niewielkimi, punktowymi zmianami w tkance miasta idzie duża zmiana społeczna.. Nie trudno rozsądzić, które z działań ma większy potencjał doprowadzenia do dobrej zmiany w mieście, bodowa fontanny na osiedlu Witosa czy 4 orlików w obrębie Załęskiej Hałdy?

2\# Inny jest przypadek dzielnicy Zarzecze. Ma ona charakter podmiejski, co wiąże się z zaludnieniem zdecydowanie bardziej ekstensywnym niż na obszarze Sródmieścia. Zajmuje za to bardzo duży obszar, w ramach którego wyodrębnić można wiele miejskich działek inwestycyjnych. Mimo braku przestrzeni publicznych jej mieszkańcy są nadspodziewanie aktywni (wysoki odsetek osób głosujących w ramach BO). Nie idzie za tym jednak możliwość realnej zmiany, ponieważ Budżet Obywatelski opiewa tu na niecałe 230 tys. złotych. Dodatkowo kwota ta wygospodarowana została przez obcięcie o $75 \%$ funduszy, którymi dysponowała do tej pory rada jednostki pomocniczej Zarzecze.

Sytuację odwrotną zastajemy w Śródmieściu. Przy gęstym zaludnieniu znajdziemy tu niewiele działek inwestycyjnych, za to nieprzerwanie toczą się kolejne prace budowlane z tytułu innych programów rozwoju, nic więc dziwnego, że mieszkańcy rozdysponowaniem 400 tys. złotych są mało zainteresowani, bijąc niechlubny rekord najniższej frekwencji. Pieniądze zostają wydane wg. woli niespełna $4 \%{ }^{20}$ obywateli. W większości zostają przeznaczone na utrzymanie elementów już istniejących oraz finansowanie instytucji, otrzymujących fundusze od Miasta w ramach innych programów. Można więc uznać, że budżet nie spełnił swoich ambicji budowania wspólnoty mieszkańców.

3\# Kwartały A i B sąsiadują ze sobą, w obu zamieszkuje podobna liczba młodych matek, jak pokazują badania, należących do jednej z najaktywniejszych w tego typu programach grup społecznych. Mają one dość podobne potrzeby. Trywializując, sprowadzić je można do założenia, iż pod oknem każdego z mieszkań znajdować powinien się: plac zabaw, parking, zielony skwer oraz wybieg dla psów. Oprócz tego pojawiają się wariantowo, propozycje boiska lub siłowni na zielonym powietrzu. I fantastycznie! Zróżnicowana oferta proponowanych w przestrzeni publicznej aktywności to motto jej odpowiedniego zaprojektowania. Przestrzeń ma jednak taką złośliwą właściwość, że jeśli chcemy by wiele rzeczy było blisko, to okazuje się, że: a.) Część z nich mimo usilnych starań, w efekcie i tak znajduje się stosunkowo daleko. b.) Każda funkcja ulega takiej minimalizacji, że za plac zabaw służą dwie huśtawki i mała karuzela, a walka o miejsca parkingowe staje się główną

19 Dane wg. Budżet Obywatelski Katowice 2015 - Raport, Załącznik nr 5 - Wyniki głosowania, dostępne: http://bo.katowice.eu/Aktualnosci/PublishingImages/Strony/Raport-/wyniki glosowania.pdf

20 Dane za: http://wiadomosci.wp.pl/kat,1019409,title,Wodny-plac-zabaw-wsrod-przyjetych-projektowbudzetu-obywatelskiego-w-Katowicach,wid,17882428, wiadomosc.html?ticaid=116516\&_ticrsn=3 
osią międzysąsiedzkich kontaktów, niespecjalnie budującą, a wybieg dla psów nie mieści więcej niż dwóch czworonogów.

Zamiast tego wystarczyłoby w ramach kilku oddzielnych projektów, zaplanować że co prawda pani z kwartału A będzie musiała zrobić sobie 5 min. spaceru żeby dotrzeć do kwartału B, ale znajdzie tam pełnowartościowy plac zabaw, a pod jej oknem usytuowany zostanie odpowiednich rozmiarów skwer. Tylko przestrzeń dla takich ustaleń nie została zorganizowana, a jak wspominałam wcześniej, brak też wizji ogólnego rozwoju dla dzielnic.

\section{Wnioski}

Budżet Obywatelski, jest krokiem w dobrą stronę w stosunku do prowadzonych do tej pory entuzjastycznie konsultacji społecznych, które zazwyczaj nie prowadziły do realizacji wypracowanych z mieszkańcami rozwiązań w życie. Mimo, iż nie stanowi w rozumienia prawa umowy wiążącej Urząd Miasta do realizacji wybranych projektów, za sporadyczne uznać można sytuacje, w których do tego nie dochodzi. Pojawia w momencie gdy zapał z których podchodzono pierwotnie do partycypacji, wygasł już niemal całkowicie z braku jej realnych efektów i pozwala wspiąć się na najwyższy ze stopni jej drabiny ${ }^{21}$.

Należy jednak pamiętać, iż konsekwencje przestrzenne działań związanych z wdrażanymi tą drogą projektów architektonicznych, urbanistycznych, a przede wszystkim rozwiązań rzutujących na planowanie przestrzenne miasta, utrzymują się w mieście znacznie dłużej niż na przestrzeni jednego czy dwóch pokoleń. Nie powinniśmy więc pozwolić na zupełnie subiektywne zawłaszczenie przestrzeni publicznych przez określone jednostki lub grupy społeczne. Podporządkowanie jej specyficznym potrzebą i poczuciu estetyki wąskich grup interesów. Dodatkowo, oddanie przestrzeni miasta jej użytkownikom [nie obywatelom], którzy w mniejszym stopniu zainteresowani są pełnionymi przez miasto funkcjami społecznymi, prowadzić może do powstawania ,nie-miejsc”22, takich jak np.: rozległe parkingi. Nie pogłębiają one w żaden sposób zakotwiczenia mieszkańców w przestrzeni miasta. Zamiast budować poczucie wspólnoty, generują jedynie iluzję posiadania pewnego fragmentu przestrzeni miejskiej, z założenia publicznej.

Nieodpowiednie dysponowanie środkami BO, powoduje pogłębianie się różnic w doinwestowaniu poszczególnych dzielnic, choć narzędzie ma potencjał ich wyrównywania. Wśród kryteriów decydujących o kwocie przyznawanej poszczególnym dzielnicą, oprócz uwzględnianej obecnie liczby mieszkańców, należałoby wprowadzić czynniki takie jak, ilość dostępnych działek inwestycyjnych, aktywność obywateli podczas poprzednich edycji BO czy średnie zarobki mieszkańców [mogące być odzwierciedleniem prestiżu dzielnicy]. Niedopracowana formuła organiacji procedury Budżetu Obywatelskiego, funkcjonująca w ramach istniejącego prawa regulującego gospodarkę przestrzenną w Polsce prowadzi do pogłębienia chaosu przestrzennego $\mathrm{w}$ zagospodarowaniu Polskich miast. BO to atrapa pełnowymiarowego budżetu partycypacyjnego, narzędzie niedopracowane, stosunkowo tania w realizacji obietnica wyborcza. W myśl zasady: skoro projekt remontu chodnika nie został wybrany do realizacji, to mieszkańcy powinni raczej w spokoju czekać na następną edycje, niż wymagać od miasta rozwiązania tej kwestii w ramach innych środków, służy on raczej zrzuceniu odpowiedzialności za przestrzeń poszczególnych dzielnic na ich mieszkańców, niż realnemu wysłuchaniu i zaspokojeniu zgłaszanych przez obywateli po-

21 Za: S. R. Arnstein, A Ladder od Citizen Participation, JAIP, Vol. 34, No. 4, July 1969, s. 216-224.

22 Pojęcie wprowadzone przez M. Auge w Nie-miejsca: wprowadzenie do antropologii hipernowoczesnośc, Wydawnictwo naukowe PWN, Warszawa 2010. 
trzeb.Wprowadza on wśród angażujących się w jego funkcjonowanie obywateli dezorientację, odnośnie kierunku rozwoju ich dzielnicy, i prowokuje do zadawania pytań które być może, w innych okolicznościach nie miałyby okazji zostać wyartykułowane. Pytań o plany Urzędu Miasta, wobec ich najbliższego otoczenia. Sygnalizuje, że nie muszą zgadzać się na status quo i może być trampoliną do dalszych działań.

\section{Weryfikacja wniosków}

Korzystając z doświadczeń podobnych inicjatyw w naszym kraju, w ramach drugiej edycji „Miejskiej Szychty” przeprowadzona zostanie uzupełnienia procedury BO o wspomniane narzędzia w ramach pilotażowego programu wdrażanego na Osiedlu Paderewskiego wraz obszarem Doliny 3 Stawów. Zaznaczam iż działania te nie są moją autorską inicjatywą, jednak biorąc w nich udział mam nadzieję testować w praktyce, próby rozwiązania problemów wskazanych w tym tekście.

\section{Literatura}

1. Szaranowicz-Kusz M. Budżet Partycypacyjny. Jak mieszkańcy moga wspótdecydować o budżecie miasta?, Fundacja Pole Dialogu, Warszawa 2014.

2. Miessen M. Koszmar Partycypacji, Fundacja Nowej Kultury Bęc Zmiana, Warszawa 2013.

3. Kraszewski D., Mojkowski K. Budżet Obywatelski w Polsce. Fundacja im. Stefana Batorego, Warszawa 2014.

4. Górski R. Bez Państwa. Demokracja uczestniczaca w działaniu. Korporacja Ha!Art, Kraków 2007.

5. Kębłowski W. Budżet Partycypacyjny ewaluacja. Instytut Obywatelski, wwarszawa 2014.

6. Kębłowski W. Budżet Partycypacyjny krótka instrukcja obstugi. Instytut Obywatelski, Warszawa 2013.

7. Praca zbiorowa pod redakcją Jaworskiego P. Raport, zawierajacy wnioski mieszkanek oraz mieszkańców Katowic dotyczace Budżetu Obywatelskiego. Napraw Sobie Miasto, Katowice 2015, dostępny: http://issuu.com/paweozyrysjaworski/docs/raport.

8. McGuirk J. Radykalne miasta. Przez Amerykę Lacińska w poszukiwaniu nowej Architektury. Fundacja Nowej Kultury Bęc Zmiana oraz Fundacja Res Publica im.H. Kraszewskiego, Warszawa 2015, [wydanie oryginalne, Verso, 2014]

9. Jałowiecki B., Sekuła E., Smętkowski M., Tucholska A. Warszawa - czyje jest miasto?, Scholar, Warszawa 2009, s. $251-258$.

10. Analiza stanu $i$ uwarunkowań prac planistycznych w gminach $w 2013$ roku. SYNTEZA, Zespół autorski: Śleszyński P. (koordynacja) Komornicki T., Deręgowska A., Zielińska B., Opracowanie wykonane dla Departamentu Polityki Przestrzennej Ministerstwa Infrastruktury i Rozwoju, Warszawa 2013, dostępna:

https://www.igipz.pan.pl/tl_files/igipz/ZGMiL/Aktualno\%C5\%9Bci/Streszczenie_za_2013.pdf.

11. Prus B. Sytuacja Planistyczna w Polsce - Studium Porównawcze. Infrastruktura i Ekologia Terenów Wiejskich, Nr 2/II/2012, Polska Akademia Nauk, Oddział w Krakowie, s. 123-135 Komisja Technicznej Infrastruktury Wsi.

12. Nowakowski M. Sto lat planowania przestrzeni polskich miast (1910 -2010). współpraca Bańskowska B., Oficyna Naukowa, Warszawa 2013, s. 394.

13. Arnstein S. R. A Ladder od Citizen Participation. JAIP, Vol. 34, No. 4, July 1969, s. 216-224.

14. Auge M. Nie-miejsca: wprowadzenie do antropologii hipernowoczesnośc. Wydawnictwo naukowe PWN, Warszawa 2010. 


\title{
Citizen's budget in Katowice and its consequences in spatial development of the city
}

\section{Karolina Studencka}

Krakow University of Technology, e-mail: studencka.karolina@gmail.com

\begin{abstract}
Participatory budgeting, known in the world for decades, arised lately wide application among Polish cities. After four years, since it was introduced in Sopot in 2011 it is high time to give it the second thought and consider how does it reflect the shape to the cities and it's districts. Based on consultation with citizens of Katowice who put their own ideas on votes since it was established there two years ago, this paper tries to diagnose threats and misconducts among participatory budgeting procedure. Despite all the advantages, in present shape, this procedure can be a couse of urban tissue disintegration. Still I considered it as a fruitful tool of social integration and a great way ti hear from the citizens.

Keywords: Participatory budgeting, Katowice, public consultation, social diagnose, spatial planning.
\end{abstract}

